\title{
Hanna Suchocka
}

Uniwersytet im. Adama Mickiewicza w Poznaniu

\section{KSZTAŁT SCENY POLITYCZNEJ W POLSCE W OKRESIE TRANSFORMACJI USTROJOWEJ}

DOI: http://dx.doi.org/10.12775/TSP-W.2016.001

\begin{abstract}
Summary. The shape of the political scene in Poland in the period of systemic transformation. The term political scene, which covers phenomena of versatile character, is very extensive and it is often used interchangeably with the expression political space. The political scene, or space, of modern countries is most often defined through references to the broadly understood party system. The experience of the transformation period demonstrates that an important role in the shaping of the political scene is played by the so-called pendulum effect. The evolution of the Polish party system and the shape of the political scene as its consequence, is still largely unpredictable.
\end{abstract}

Keywords: political parties; political scene; party system; period of systemic transformation.

Riassunto. La costruzione della scena politica polacca nel periodo costituzionale transitorio. Il concetto della scena politica è estremamente ampio, comprende vari fenomeni e spesso viene usato in un modo intercambiabile con il termine spazio politico. Generalmente, 1 'arena o lo spazio politico degli stati moderni è determinato in riferimento al sistema partitico in senso lato. L'esperienza del periodo transitorio polacco mostra che un ruolo significativo nella formazione della scena politica viene svolto dal cosiddetto effetto pendolo. L'evoluzione del sistema partitico polacco, e conseguentemente la forma della scena politica, sono tuttavia ancora imprevedibili.

Parola chiave: partiti politici; scena politica; sistema partitico; periodo costituzionale transitorio. 


\section{KSZTAŁT SCENY POLITYCZNEJ W POCZĄTKACH TRANSFORMACJI - SYSTEM PARTYJNY A SIŁY SPOŁECZNE. SPECYFIKA OKRĄGŁEGO STOŁU}

Zmierzając się z tematem dotyczącym transformacji ustrojowej w różnych aspektach, czy to politycznym, ekonomicznym, czy prawnym, zawsze powstaje zasadnicze pytanie dotyczące precyzyjnego dookreślenia zakresu czasowego, jaki obejmujemy terminem transformacja. Czy można zjawisko transformacji zamknąć w wyraźnie określone ramy czasowe i odnieść je już tylko do przeszłości? Mam poważne wątpliwości, czy takie podejście byłoby możliwe i właściwe zarazem. Można chyba zgodzić się, że proces transformacji ustrojowej w różnych formach trwa nadal. Choć być może mamy już tutaj do czynienia z pewnym efektem „po-transformacyjnym” i tak być może należałoby nazwać obecny okres, aby odróżnić go od tego pierwszego, swoistego okresu pionierskiego. Mam jednak pełną świadomość, że także ten termin nie jest precyzyjny. W naturalny zatem sposób cenzura 25 lat od rozpoczęcia procesu transformacji jest taką ramą, która pozwala w sposób zasadniczo uporządkowany racjonalnie analizować zachodzące przemiany mające wpływ na kształt sceny politycznej, zarówno $\mathrm{w}$ aspekcie konstytucyjnym jak i stricte politycznym. I taki też zakres czasowy, tj. od 1989-2015 r., nadałam moim (siłą rzeczy bardzo skróconym z uwagi na ogrom materiału) rozważaniom.

Kolejnym pojęciem, z którym przyszło mi się zmierzyć to pojęcie „kształtu sceny politycznej”. Samo pojęcie „scena polityczna” jest niezwykle pojemne. Obejmuje bardzo zróżnicowane zjawiska. Używa się go często zamiennie z określeniem „,przestrzeń polityczna”. Najczęściej jednak scenę polityczną czy przestrzeń polityczną państw współczesnych określa się poprzez odniesienia do systemu partyjnego w szerokim rozumieniu. Taki jest też kontekst moich refleksji.

Dla potrzeb niniejszych rozważań starałam się dokonać pewnego podziału całego okresu określanego jako „transformacja” na podokresy, które miały istotny wpływ na zmiany ustrojowe i polityczne, a tym samym wyznaczały kierunki decydujące o kształcie polskiej sceny politycznej z punktu widzenia roli partii politycznych.

Rozważania moje rozpoczynam odwołując się do roku 1989. Tego roku bowiem sięgają korzenie systemu politycznego i systemu partyjnego, jaki ukształtował się w Polsce w okresie transformacji.

Rok 1989 to był szczególny czas. Uważam, że można go scharakteryzować jako „rok polityczny” w różnych jego wymiarach. Właściwie jako „rok polityczny" rozpoczął się parę tygodni wcześniej, jeszcze zanim zaczął się kalendarzowy rok 1989. Datą tą jest 18 grudnia 1988 r., kiedy to powołany został w Warsza- 
wie, półlegalny wówczas, Komitet Obywatelski przy Przewodniczącym NSZZ „Solidarność” Lechu Wałęsie, przekształcony później w Komitet Obywatelski „Solidarność”. Członkami tego komitetu byli działacze opozycji podziemnej, inteligencja warszawska, ludzie Solidarności ${ }^{1}$. Miał on wszelkie cechy „gabinetu cieni". Powołano w jego składzie 15 komisji, które - w jakimś sensie - odpowiadały działom w strukturze rządowej. Ukonstytuowanie się tego komitetu, według mnie, uznać należy za kluczowe dla nadania początku kształtowania się nowej sceny politycznej w Polsce.

Pojawia się organizacja, komitet, ruch, który wykracza w istotnym stopniu poza konstytucyjnie zakreślone zasady działania tego typu organizacji. Obowiązuje wówczas przecież konstytucja PRL, której jedną z zasad ustrojowych jest istnienie kierowniczej roli partii komunistycznej. Art. 3 ust. 1 Konstytucji stwierdzał, że: „Przewodnia siłą polityczną w budowie socjalizmu jest PZPR”. System partyjny zatem jest konstytucyjnie określony. Nawet jeśli dopuszcza się istnienie innych organizacji i nawet jeśli przydaje im się określenie partii politycznej (choć nie w oficjalnej nazwie), to nie posiadają one, ze swojej istoty, atrybutów partii politycznej. Nie są włączone w pluralistyczny system walki o władzę. Celem wyborów bowiem nie jest zmiana partii rządzącej, gdyż rola partii rządzącej, określanej jako przewodnia siła polityczna jest zadeklarowana konstytucyjnie od 1976 r. Wybory, mające charakter swoistego plebiscytu, mają i mogą tylko potwierdzić hegemonię przewodniej partii. Jest to zatem system monopartii, budowany na antytezie pluralizmu.

Przyjęcie tego typu założenia ustrojowego wywoływało określone konsekwencje:

1) istnienie partii opozycyjnych nie było możliwe;

2) mogły istnieć stowarzyszenia, które opisywano jako partie, ale które musiały uznawać kierowniczą rolę głównej partii;

3) wybory odbywały się w oparciu o jedną listę;

4) żadne inne organizacje nie tworzyły odrębnych list wyborczych, które mogłyby konkurować z partią posiadająca atrybut partii kierowniczej.

W tak zatem określonej (konstytucyjnie i politycznie) sytuacji pojawia się organizacja - „Komitet Obywatelski”, która w sposób istotny wyłamuje się z tych reguł. Staje się „nieformalnym” reprezentantem części społeczeństwa, który nie identyfikuje czy, lepiej mówić, przestaje identyfikować się z istnie-

${ }^{1}$ Nie wszystkie istniejące nielegalnie organizacje opozycyjne weszły w skład KO. Nie znalazły się tam np. KPN, Solidarność Walcząca, Polska Partia Niepodległościowa.

2 Art. 3 Konstytucji PRL znowelizowanej w 1976 r. W ust. 2 tego artykułu stwierdzano, że „Współdziałanie PZPR, ZSL i SD stanowi podstawę FJN”. 
jącym systemem partyjnym i politycznym. Organizacja ta staje się swoistym wehikułem zaktywizowania politycznego społeczeństwa. Ta klasyczna rola przypisywana partiom politycznym, jaką jest aktywizacja społeczeństwa, przesuwa się w stronę organizacji, która świadomie nie określa się jako partia polityczna.

Od pewnego czasu mówiło się w Polsce o konieczności zorganizowania rozmów przy wspólnym stole, ale było to w sferach projekcji. Władza komunistyczna jeszcze w roku 1987 i na początku 1988 sądziła, że uda się włączyć przedstawicieli opozycji do istniejącego układu partyjno-politycznego (proponowano np. teki ministerialne dla ważnych przedstawicieli opozycji w rządzie) bez rozpoczynania procesu formalnych rozmów z bardziej zorganizowaną instytucjonalnie opozycją.

Wówczas, po powołaniu Komitetu Obywatelskiego stało się już jasne, że znalezienie połowicznego rozwiązania poprzez rozmowy z indywidualnymi przedstawicielami opozycji i odkładanie rozmów Okrągłego Stołu nie jest możliwe. Zaczęły się pierwsze ruchy zmierzające do innego ukształtowania się sceny politycznej. Niezależnie od sporów politycznych, jakie toczą się do dzisiaj co do oceny rozmów Okrągłego Stołu, z punktu widzenia kształtowania się pluralistycznej struktury partyjnej i nowej sceny politycznej zdarzenie to miało niezwykle ważne znaczenie.

Komitet Obywatelski musiał się ukonstytuować i wyłonić reprezentację opozycji na negocjacje z tzw. stroną partyjno-rządową. Jako sprawę naczelną postawiono legalizację „,Solidarności”, która stanowiła więcej niż warunek wstępny rozmów - określała ich sens. Wysuwając ten postulat na czoło, opozycja wyraźnie też dawała władzy do zrozumienia, że nie da się skusić ofertami udziału w życiu politycznym bez legalizacji „Solidarności”’3.

Nakreślony został przez opozycje kierunek oczekiwanych reform, a nazwany on został „Od państwa partii, państwa jednej partii do państwa narodu i społeczeństwa", a więc do pluralizmu. Nakreślenie tego kierunku i jego nazwanie jest znamienne. Wyartykułowana w nim została wyraźnie tendencja ,antypartyjna”, prezentowano wizję państwa jako uwolnionego od partii.

W tym duchu przystępowano też do podpisania porozumień. Podpisane 5 kwietnia 1989 r. porozumienia zawierały kilka kluczowych, z punktu widzenia kształtowania się nowej sceny politycznej, postanowień:

1) przede wszystkim powrót „Solidarności”, formalnie jako związku zawodowego, na scenę polityczną, a faktycznie jako ruchu społecznego, oczywiście nie jako partii politycznej;

3 Por. szerzej J. Skórzyński, Obywatelski gabinet cieni, „Polityka” 4 listopada 2009. 
2) rozpisanie nowych wyborów do parlamentu;

3) uznanie, że „Solidarność” będzie mogła stworzyć swoje własne listy kandydatów do Sejmu i do Senatu i ustalenie proporcji politycznych w wyborach do Sejmu, wedle których „Solidarność” będzie mogła obsadzić 35\% miejsc;

4) przywrócenie drugiej izby parlamentu Senatu i zagwarantowanie, że wybory do Senatu będą w 100\% wolne.

Te porozumienia były zaczątkiem zmiany przegrupowywania sceny politycznej. Po raz pierwszy od 40 lat partia komunistyczna (formalnie i konstytucyjnie przewodnia) nie miała wpływu na kształt list wyborczych jednego ugrupowania, jakim była „Solidarność”. Był to istotny wyłom otwierający drogę do pluralistycznego systemu partyjnego. Z perspektywy czasu wydaje się to normalne i zwyczajne, ale w ówczesnych warunkach był to historyczny przełom.

Konsekwencją porozumień Okrągłego Stołu była nowelizacja konstytucji dokonana w kwietniu 1989 r. Zmiany nie objęły jednak art. 3 dotyczącego kierowniczej roli partii. Miało to być swoiste konstytucyjne „zabezpieczenie” polityczne przewodniej roli partii. Jednak w świetle porozumień dopuszczających „Solidarność" do wyborów z własnymi listami wyborczymi, pozostawienie tego przepisu stanowiło wyraźną niekonsekwencję. Dopuszczono bowiem do tego, że 35\% miejsc w Sejmie i 100\% w Senacie znajdowało się poza kontrolą partii pełniącej przewodnią rolę.

Przyznano także szczególne kompetencje prezydentowi, który mógł ingerować w sytuacji, w której zmiany polityczne zmierzałyby w niewłaściwym ustrojowo kierunku. Prezydent uzyskał prawo rozwiązania Sejmu, gdy Sejm uchwali ustawę lub podejmie uchwałę uniemożliwiającą prezydentowi wykonywanie jego konstytucyjnych funkcji określonych w art. 32 ust. 2 Konstytucji, tj. czuwania nad przestrzeganiem konstytucji, stania na straży suwerenności i bezpieczeństwa państwa, nienaruszalności i niepodzielności jego terytorium oraz przestrzegania międzynarodowych sojuszy politycznych i wojskowych. O ile dwie pierwsze przyczyny rozwiązania parlamentu można zaliczyć do klasycznych przyczyn znanych systemowi parlamentarnemu, o tyle przyczyna trzecia jest dość szczególna. Raczej nie ulega wątpliwości, że miała ona wyraźnie charakter polityczny. Miała zapobiec właśnie zmianie ustroju. Te swoiste kotwice poprzedniego systemu nie odgrywały już jednak roli w praktyce. W zderzeniu $\mathrm{z}$ „konstytucją rzeczywistą” przepisy te okazały się fikcyjne. 


\section{SCENA POLITYCZNA PO WYBORACH Z 4 CZERWCA 1989 R. KSZTAŁT KLUBÓW PARLAMENTARNYCH. SIŁA MNIEJSZOŚCI LEŻĄCA W JEJ LEGITYMIZACJI POLITYCZNEJ (SPOŁECZNEJ)}

Wybory, jakie odbyły się 4 czerwca przeprowadzono zatem na innych zasadach niż wszystkie dotychczasowe wybory od 1945 r. Nie były one bowiem tylko swoistym rodzajem manifestowania poparcia dla rządzącej partii komunistycznej. Skład personalny przyszłego parlamentu, w odróżnieniu od wszystkich dotychczasowych wyborów, nie był z góry przesądzony.

Po raz pierwszy odrzucono zasadę jednej listy wyborczej. Pozostawiono jednak tzw. listę krajową, na której znajdowały się nazwiska liderów partii, stronnictw politycznych i stowarzyszeń powiązanych z partią kierowniczą czy należących do wspólnego Frontu Wyborczego. Na liście krajowej nie było nazwisk liderów „Solidarności” zgodnie z wolą samych liderów. Także ta lista miała być wyraźną, kolejną kotwicą istniejącego układu partyjno-politycznego.

Przełomową sprawą dla kształtu przyszłej sceny politycznej było odrzucenie w wyborach 4 czerwca listy krajowej. Masowe głosowanie przeciwko kandydatom umieszczonym na liście krajowej spowodowało, że w Sejmie nie zasiedli prominenci związani z poprzednim systemem partyjno-rządowym. Członkowie koalicyjnych partii i stowarzyszeń, którzy wybrani zostali z list w swoich okręgach znaleźli się w Sejmie bez głównych liderów politycznych. Ci bowiem pozostali, w wyniku decyzji wyborców, poza Sejmem.

Uważam, że odrzucenie listy krajowej było pierwszym krokiem na drodze do rozmontowywania porozumień Okrągłego Stołu, niecałe 2 miesiące po ich podpisaniu. Wszak lista krajowa miała być jedną z gwarancji zapewniającej kierownictwo partii komunistycznej, a więc być gwarancją dotychczasowego układu politycznego. Jej odrzucenie stwarzało nową sytuację. To niezwykle osłabiło ówczesny układ rządzący oraz miało istotny wpływ na kształt przyszłej sceny politycznej.

Z trudem już udało się wybrać gen. Jaruzelskiego na prezydenta państwa. Nowo wybrani posłowie z ramienia Komitetów Obywatelskich, kiedy znaleźli się w Sejmie nie czuli się związani politycznymi porozumieniami swoich liderów z okresu Okrągłego Stołu.

Wybrano jeszcze co prawda kandydata na przyszłego premiera w osobie gen. Kiszczaka, ale nie był on już w stanie sformułować rządu. Opuścili go sojusznicy ugrupowań satelickich. To już była inna dynamika polityczna. Sztuczny gorset kierownictwa jednej partii został rozerwany i w to miejsce zaczęły wkraczać normalne reguły gry parlamentarnej, prowadzące do zmieniających się układów koalicyjnych. 
Można było już wówczas, na samym początku zaobserwować zjawiska znane nam z klasycznych systemów demokratycznych, tj. zmiany koalicjanta w obliczu zmieniającej się sytuacji politycznej. W związku z niemożnością powołania rządu przez C. Kiszczaka zawiązała się nowa koalicja, montowana przez L. Wałęsę wokół komitetów obywatelskich i dwóch byłych ugrupowań sojuszniczych PZPR, tj. ZSL i SD. Wałęsa, jako lider Komitetu Obywatelskiego (a nie jako prezydent, którym wtedy nie był), wskazał kandydata na premiera w osobie niepartyjnego T. Mazowieckiego. Wskazanie Mazowieckiego nie związanego z żadną partią polityczną było swoistą realizacją tego zasygnalizowanego na początku przemian kierunku, tzn. tworzenia państwa dla społeczeństwa, państwa „partyjnie neutralnego” czy też państwa apartyjnego, w odróżnieniu od państwa partyjnego.

Taki sceptycyzm dotyczący tworzenia partii politycznych był widoczny i do pewnego stopnia był zrozumiały w wielu państwach postsocjalistycznych w początkowym okresie transformacji. Był on bowiem oparty na negatywnej ocenie poprzedniego systemu partyjnego. Tendencja odrzucania instytucji, które w szczególny sposób uległy deformacji w minionym systemie, była szczególnie widoczna w pierwszych latach transformacji. W odniesieniu do partii politycznych, znalazło to m.in. swój wyraz symboliczny w postaci konsekwentnego unikania nazwy ,partia” w sytuacji tworzenia nowych organizacji, które z istoty swojej, z uwagi na swoją funkcję i cel, de facto, były partiami politycznymi. Poszukiwano różnych określeń zastępczych innych niż słowo partia, chyba że używano swoistej zbitki słownej w nazewnictwie, która sama w sobie nadawała pojęciu partia inny wymiar, także jakby odbijający się od poprzedniego systemu, np. „partia piwa” w Polsce. Już to samo zderzenie słów rozbijało koturnowość pojęcia partii.

Głosy krytyczne dotyczące w ogóle roli partii politycznych we współczesnych systemach ustrojowych, można było słyszeć nie tylko u nas. Wieszczono koniec tego co było znane jako państwo partyjne. Wynikało to z faktu, że opinia publiczna w wielu demokratycznych systemach (i to nie tylko autorytarnych) wyrażała niezadowolenie, połączone z brakiem zaufania do partii politycznych. Stąd też można było odnotować dyskusję zwłaszcza w pewnych środowiskach naukowych o zaniku roli partii politycznych ${ }^{4}$. Uważam jednak, że w dużej mierze pozytywny czy negatywny stosunek do takiej tezy wynika raczej z emocjonalnego oglądu rzeczywistości aniżeli z rzetelnej analizy badawczej zjawiska partii politycznej współcześnie. Nie ulega bowiem wątpliwości, że przychylić się

${ }^{4}$ R. Gunther, J. Ramon Montero, J. J. Linz (eds.), Political Parties: Old Concepts and New Challenges, Oxford University Press 2002, p. 291. 
należy do tezy o potrzebie istnienia partii politycznych także we współczesnych warunkach, niezależnie od rozpowszechnianego sceptycyzmu co do potrzeby ich istnienia.

Stąd też zauważyć można, że zmiana systemu politycznego w Polsce od autorytarnego w kierunku systemu demokratycznego powiązana jest raczej nie tyle z odchodzeniem od partii politycznych, ale raczej ze zmieniającą się rolą partii politycznych. Nie był to tylko przykład Polski. Negatywny fenomen jednopartyjnego państwa był wspólnym doświadczeniem wszystkich państw Europy Środkowej i Wschodniej. Wszystkie też one po rozpadzie komunizmu próbowały tworzyć czy odtworzyć pluralistyczny system partyjny zgodnie z przekonaniem, że partie polityczne były i są pojmowane jako wehikuły współczesnej demokracji ${ }^{5}$.

Jak już zaznaczyłam, jednym z elementów tego zmieniającego się stanowiska w stosunku do partii politycznych było szukanie nazw zastępczych. Zamiast słowa partia używano innego określenia. Bardzo powszechnym stało się słowo ruch, komitet, który w istocie swojej posiadał cechy klasycznej partii demokratycznej. Wyraźnym przykładem takiego właśnie zabiegu socjologicznego był wymieniony już powyżej Komitet Obywatelski „Solidarność”. Spełniał on w 1989 r. wszystkie istotne warunki i funkcje przypisywane partii politycznej, tj.:

1) skupianie różnych podstawowych interesów występujących w społeczeństwie;

2) integrowanie wyborców w procesie demokratycznym poprzez wybory, ale także inne formy uczestnictwa;

3) formułowanie programów politycznych i propozycji dla centralnych i lokalnych agend oraz stwarzanie platform dla mobilizowania społecznego wsparcia;

4) wybór politycznego przywództwa oraz szerzej politycznych elit ${ }^{6}$.

$\mathrm{Z}$ uwagi na te cechy odgrywał on kluczową rolę w organizacji wyborów do parlamentu, zarówno w procesie przygotowywania list, jak i prowadzenia kampanii wyborczej.

Po zwycięskich wyborach do parlamentu wygranych przez KO ,Solidarność" utworzony został odpowiedni klub parlamentarny z nim powiązany, noszący nazwę Obywatelskiego Klubu Parlamentarnego. Zdecydowana większość

${ }^{5}$ B. Lai, R. Melkonian-Hoover, Democratic Progress and Regress: the Effect of Parties on the Transitions of States to and Away from Democracy, "Political Research Quarterly" 2005, vol. 58/4, p. 551 i nast.

${ }^{6}$ R. Gunther, L. Diamond, op. cit., oraz Analitical paper on the IPU survey concerning the impact of political party control over the exercise of the parliamentary mandate, Z. Kędzia, A. Hauser, Chair of Constitutional Law, Adam Mickiewicz University (niepublikowany). 
aktywnych członków Komitetu Obywatelskiego (z wyjątkiem Lecha Wałęsy oraz T. Mazowieckiego i związanych z nim osób) znalazła się w klubie parlamentarnym. I to właśnie klub parlamentarny nazwany „obywatelskim” zaczął pełnić kluczową rolę polityczną i zastępować Komitet Obywatelski. Użyte w nazwie klubu określenie „obywatelski” miało też wyraźnie sugerować odniesienia do dobra wspólnego, do postaw obywatelskich i tym samym zaznaczyć zerwanie z mającym negatywne odniesienia partyjnym podziałem społeczeństwa ${ }^{7}$.

W Sejmie tzw. „Okrągłostołowym” OKP nie był klubem najliczniejszym. Najwięcej posłów, z uwagi na zawarte przed wyborami porozumienie, miała $\mathrm{PZPR}^{8}$. OKP miał jednak siłę moralną i stąd stał się głównym motorem przekształceń ustrojowych, nie zważając na zawarte w kwietniu porozumienia, mające w zamyśle nie doprowadzać do zasadniczych zmian ustroju i całkowitego przekształcenia sceny politycznej.

Obecnie była to już inna rzeczywistość polityczna. Równocześnie jednak konieczne okazało się dokonanie dalszych zmian o charakterze konstytucyjnym.

\section{ODEJŚCIE OD POROZUMIEŃ OKRĄGŁEGO STOŁU - ZMIANY W KONSTYTUCJI Z GRUDNIA 1989 R. - STWORZENIE PODWALIN KONSTYTUCYJNYCH POD NOWĄ SYTUACJĘ POLITYCZNĄ}

Zasadniczych zmian będących konsekwencją tej ewolucji politycznej dokonano w grudniu 1989 r. Zmiana konstytucji dokonana w grudniu 1989 r. przekreśliła ostatnie pozostałości zawartego przy Okrągłym Stole układu politycznego, który już i tak okazał się martwy. Wśród tych zmian konstytucyjnych wykreślono także art. 3 o przewodniej roli partii w budowie socjalizmu, co było logiczną konsekwencją dynamicznie zmieniającej się rzeczywistości politycznej.

Wówczas w miejsce tego przepisu wprowadzono do konstytucji (w rozdz. I o podstawach ustroju politycznego i gospodarczego) art. 4 dotyczący partii politycznych o następującej treści: 1. „Partie polityczne zrzeszają na zasadach dobrowolności i równości obywateli RP w celu wpływania metodami demokratycznymi na kształtowanie polityki państwa. 2. O sprzeczności z Konstytucją celów lub działalności partii politycznej orzeka TK"

7 Obywatelski Klub parlamentarny „Solidarność” w swojej części sejmowej liczył 161 posłów na 460 posłów oraz 99 na 100 senatorów.

${ }^{8}$ Najwięcej posiadał PZPR - 173 miejsca. Stronnictwa koalicyjne odpowiednio: ZSL - 76, SD - 27, „PAX” - 10, UChS - 8, PZKS - 5, łącznie posiadały 299 miejsc.

9 Ustawa z dnia 29 grudnia 1989 r. o zmianie Konstytucji PRL, Dz. U. z 1989 Nr 75, poz. 444. 
W artykule tym zawarta została podstawowa zasada ustrojowa, jaką jest zasada pluralizmu partyjnego i dobrowolności tworzenia partii politycznych, a zarazem zasada posługiwania się metodami demokratycznymi w celu wpływania na kształtowanie polityki państwa.

Zatem zasada pluralizmu politycznego opartego na dobrowolności tworzenia partii politycznych podniesiona została już w grudniu 1989 r. do rangi podstawowej zasady ustrojowej.

Od strony katalogu praw jednostki natomiast podstawą do tworzenia partii politycznych był do 1997 r., tj. do czasu uchwalenia nowej konstytucji polskiej, ogólny przepis dotyczący wolności stowarzyszeń. Było to rozwiązanie odpowiadające rozwiązaniom Europejskiej Konwencji Praw Człowieka, która w art. 11 mówi o wolności stowarzyszania się, nie zawierając odrębnej regulacji dotyczącej prawa do tworzenia partii politycznych.

Państwa postsocjalistyczne jednak, z uwagi na negatywne doświadczenie historyczne, wybrały w większości drogę uregulowania prawa do tworzenia partii politycznych bezpośrednio na poziomie konstytucyjnym. Wolność tworzenia partii politycznych była postrzegana jako jedna z podstaw tworzenia demokratycznego systemu politycznego, wymagająca konstytucjonalizacji. Także ustrojodawca polski, uchwalając pełną nową konstytucję w 1997 r., zawarł w niej art. 11 o prawie do tworzenia partii politycznej, niezależnie od art. 58 o wolności stowarzyszenia.

Konsekwencją rozwiązań konstytucyjnych było przyjęcie ustawy o partiach politycznych ${ }^{10}$. Zaznaczyć jednak trzeba, że przyjęcie odrębnej ustawy o partiach politycznych nie było podstawowym wymogiem demokratyzacji ustroju. Stwierdziła to wręcz Komisja Wenecka uznając, że: „odrębna ustawa o partiach politycznych nie jest wymogiem dla funkcjonowania demokracji i jak zaznaczyła, być może będzie najbardziej efektywna kiedy będzie bardzo zwięzła w regulacji”. Mimo to jednak nie tylko Polska, ale także większość państw Europy Środkowej i Wschodniej przyjmowała odrębne ustawy o partiach politycznych, wyróżniając tym samym partie polityczne, ich znaczenie od innych stowarzyszeń. Głównym celem, jak już zaznaczono, takiej koncepcji legislacyjnej było podkreślenie szczególnego znaczenia partii politycznych dla funkcjonowania demokracji.

W państwach, w których takie ustawy istnieją, różnią się one zarówno zakresem, jak i sposobem regulacji ${ }^{11}$. Wpływ na to miały różne czynniki, podobnie

${ }^{10}$ Ustawa o partiach politycznych z 27 czerwca 1997 r. Dz.U. z 1997 Nr 98, poz. 604. zmiany Dz.U. z 2015, poz. 1485.

${ }^{11}$ O zapotrzebowaniu na tego typu „wskazówki” świadczy także zorganizowana m.in. z udziałem komisji weneckiej konferencja w Bukareszcie na temat systemów partyjnych w 2013 r. 
jak i przy regulacji innych materii. Należą do nich w szczególności: polityczne doświadczenie danego państwa, jak swoista tradycja legislacyjna, mająca istotny wpływ na metodę regulowania poszczególnych kwestii ustrojowych ${ }^{12}$.

\section{EWOLUCJA POLSKIEJ SCENY POLITYCZNEJ BĘDĄCA KONSEKWENCJĄ EWOLUCJI SYSTEMU PARTYJNEGO}

Zależności pomiędzy ewolucją systemu partyjnego a kształtowaniem się polskiej sceny politycznej są wyraźne. Swoiste idealistyczne założenie - utrzymania jedności środowiska postsolidarnościowego, jakie leżało u podstaw tworzenia Komitetu Obywatelskiego przy Lechu Wałęsie i następnie obywatelskiego Klubu parlamentarnego w Sejmie - bardzo szybko okazało się mrzonką. Kluczowym momentem była decyzja o kandydowaniu w wyborach prezydenckich w 1990 r. i stanięciu przeciwko sobie dwóch liderów solidarnościowych - Lecha Wałęsy i Tadeusza Mazowieckiego. W tej kampanii wyborczej ugrupowania postsolidarnościowe przestały działać przeciwko wspólnemu ,przeciwnikowi”, jakim była Polska Zjednoczona Partia Robotnicza, a zaczęły działać przeciwko sobie. Fakt ten miał przemożny wpływ na późniejszy kształt sceny politycznej. Doprowadził do stworzenia dwóch zasadniczych bloków na gruncie dawnego OKP, utworzonych wokół dwóch kandydatów solidarnościowych kandydujących na urząd prezydenta. Kolejna tendencją po rozpadzie OKP było tworzenie mniejszych partii politycznych budowanych w oparciu o ambicje personalne kolejnych polityków dawnego wspólnego obozu solidarnościowego. Po drugiej, umownie nazwanej postkomunistycznej stronie sceny politycznej, tworzyła się nowa lewica, jaka powstała po rozwiązaniu PZPR w styczniu 1990 r. ${ }^{13}$

${ }_{12} \mathrm{Z}$ uwagi na tę możliwą różnorodność regulacji rola komisji weneckiej była niezwykle istotna w promowaniu pewnego standardu ogólnego. Wiele projektów ustaw kierowanych było pod ocenę komisji. Komisja wyrażała opinie m.in. w odniesieniu do ustaw w następujących państwach: Armenia (CDL-AD(2003)005), Azerbaijan (CDL-AD(2004)025), Mołdawia (CDL-AD(2003)008), Ukraina (CDL-AD(2002)017), Bośnia-Herzegowina CDL-AD(2008)002, Bułgaria (CDL-AD(2008)034), Turcja (CDL-AD(2009)006), Serbia (CDL-AD(2010)048), Gruzja (CDL-AD(2011)044), Federacja Rosyjska (CDL-AD(2012)003). Raportem, który stanowił swoiste zebranie opracowań tematycznych był raport o charakterze generalnym z 2010 r.: CDL-AD(2010)024 Guidelines on Political Party Regulation przygotowany wspólnie przez Komisje wenecką i OBWE /ODIHR.

${ }^{13}$ W miejsce PZPR powstały 3 partie polityczne: Związek Komunistów Polskich „Proletariat”, Socjaldemokracja RP oraz Polska Unia Socjaldemokratyczna. Także one podlegały stałej przemianie. 
Z tego też względu Sejm wybrany 4 czerwca 1989 r. dochodził swojego kresu po niecałych dwóch latach istnienia. Ukształtowała się zupełnie inna, nowa struktura partyjno-polityczna aniżeli ta, która istniała na początku kadencji Sejmu w czerwcu 1989 r. Nie było już żadnych podstaw, żadnych argumentów politycznych na rzecz utrzymywania tego systemu. Wszystkie „kotwice”, które miały zabezpieczać i gwarantować utrzymanie władzy przez poprzedni układ, w tym także nie do końca wolne wybory do Sejmu, zostały zerwane. Stąd pojawiła się silna tendencja do przeprowadzenia nowych wyborów, wspierana dodatkowo argumentacją, że brak wolnych wyborów zamyka nam drogę do członkostwa w Radzie Europy.

Na koniec kadencji tego Sejmu jesienią 1991 r. skład partyjny Sejmu był niezwykle rozdrobniony. Dwa najważniejsze ugrupowania PZPR i OKP Solidarność w zasadzie przestały istnieć. $\mathrm{W}$ ich miejsce powstało wiele nowych małych partii.

W wyniku wyborów, jakie odbyły się 27 października 1991 r. ${ }^{14}$ do Sejmu weszło 29 komitetów wyborczych, z czego 11 posiadało zaledwie jednego posła. Ordynacja wyborcza bowiem nie przewidywała żadnego progu wyborczego, co miało istotny wpływ na kształt tego Sejmu i, powiedziałabym więcej, na dalsze losy polityczne kraju. Fragmentacja sceny politycznej szczególnie po stronie prawicowej (postsolidarnościowej) spowodowała destabilizację i miała swoje istotne konsekwencje w obszarze stabilności i funkcjonowania rządów. Okres parlamentu 1991-1993 wykazał niezwykle silną zależność pomiędzy systemem partyjnym i opartym na nim systemie wyborczym a trwałością i efektywnością rządu.

Animozje, zwłaszcza pomiędzy partiami utworzonymi na gruncie rozpadu klubu parlamentarnego OKP, uniemożliwiały tworzenie koalicji parlamentarnych i trwałych większości parlamentarnych. Bezpośrednio po wyborach spowodowało to niemożność sformułowania gabinetu przez B. Geremka, któremu prezydent L. Wałęsa - zgodnie z zasadami - jako zwycięskiemu ugrupowaniu, którym była Unia Demokratyczna, ${ }^{15}$ powierzył misję utworzenia rządu. Stworzony został koalicyjny rząd J. Olszewskiego, który upadł w czerwcu 1992 r. Jego następca, wskazany przez L. Wałęsę szef PSL W. Pawlak nie był w stanie

14 Wybory zarządzono na jesień 1991 r., skracając kadencję Sejmu wybranego w 1989 r. Wybory odbyły się na podstawie ustawy z dnia 28 czerwca 1991 - Ordynacji wyborczej do Sejmu Rzeczypospolitej Polskiej (Dz.U. Nr 59, poz. 252). Wybory były powszechne, bezpośrednie, równe i wolne oraz odbywały się według zasady proporcjonalności.

${ }^{15}$ Unia Demokratyczna uzyskała najwięcej bo 13,48\% mandatów. Zaraz potem uplasował się Sojusz Lewicy Demokratycznej - 13,04\% mandatów, KLD - 8,04\% oraz Wyborcza Akcja Katolicka-10,65\%. 
powołać rządu. 11 lipca 1992 r. powołano nowy koalicyjny rząd, którym przyszło mi kierować. Składał się z 7 drobnych partii. Wspierany był przez klub parlamentarny „Solidarność”, który nie wchodził w skład rządu. Spory międzypartyjne dotyczące realizacji programu gospodarczego doprowadziły do sytuacji, w której rząd stał się mniejszościowym. Zgłoszone w tej sytuacji zwykłe, a nie konstruktywne votum nieufności, co dopuszczała Mała Konstytucja uchwalona we wrześniu 1992 r., zostało przegłosowane 1 głosem i doprowadziło do przedterminowego rozwiązania parlamentu przez prezydenta.

Można zatem powiedzieć, że 4 lata, jakie minęły od wyborów w 1989 r. nie doprowadziły do ustabilizowania sceny politycznej. Fragmentaryzacja partii politycznych i zmienne koalicje powodowały płynność sceny politycznej i krótkotrwałość rządów. W zasadzie w ciągu tych czterech lat przeciętna długość trwania rządu wynosiła około roku.

Negatywne doświadczenia tych lat spowodowały zmianę ordynacji wyborczej i wprowadzenie progu wyborczego 5\% dla partii politycznej i $8 \%$ dla koalicji partii. Z progu zwolnione były komitety wyborcze organizacji mniejszości narodowych.

Wybory przeprowadzone jesienią 1993 r., odbywające się pod rządami nowej ordynacji wyborczej, wykazały wyraźnie przesunięcia nastrojów społecznych w kierunku lewicy. Z uwagi na niemożność porozumienia się stronnictw postsolidarnościowych przed wyborami w celu utworzenia koalicji wyborczej, a zarazem w związku z przesunięciem się nastrojów społecznych w kierunku lewicy, wybory zakończyły się zwycięstwem ugrupowań skupionych w koalicji Sojuszu Lewicy Demokratycznej, a więc ugrupowania o charakterze socjaldemokratycznym ${ }^{16}$.

Jak podkreśla się w literaturze, uchwalenie nowej ordynacji z progami wyborczymi ograniczyło liczbę drobnych partii w parlamencie i przyczyniło się do uporządkowania sceny politycznej. Przyniosło jednak, z drugiej strony, pewne zniekształcenie woli wyborców. Efekt był taki, że zwycięzca wyborów - SLD otrzymawszy niewiele ponad 20,5\% Głosów, miał prawie 40\% mandatów w Sejmie. Drugi był PSL, który z 15-procentowym poparciem otrzymał prawie 30\% mandatów.

Siły postsolidarnościowe znalazły się w dużej części poza parlamentem. Niemalże wszystkie formacje prawicowe nie przekroczyły progu wyborczego. Znamienne jest, że podobny fenomen po 4 latach nastąpił także w innych państwach postkomunistycznych.

16 SLD uzyskało 20,41\% mandatów, PSL - 15,40\%, a Unia Demokratyczna tylko 10,59\%. 
Niezależnie od tego efektu negatywnego, jaki nastąpił w wyborach 1993 r., wprowadzenie zasady progu wyborczego było niezwykle ważnym krokiem na drodze do zlikwidowania rozdrobnienia partyjnego w Sejmie i osłabiania systemu partyjnego. Wprowadzenie progu wyborczego zdecydowało o tym, że w kolejnych wyborach parlamentarnych liczba partii (komitetów wyborczych) dostających się do Sejmu, tj. przekraczających próg wyborczy, była pomiędzy 5 a 6 partiami. W dużej mierze wywarło to istotny wpływ na kształt sceny politycznej. Mniejsze partie wyciągnęły lekcję z przeszłości i zawierały koalicje wyborcze. Taką koalicją była na przykład Akcja Wyborcza Solidarność w 1997 r., która zebrała te partie postsolidarnosciowe, jakie nie dostały się do Sejmu w 1993 r., i po zwycięstwie w wyborach 1997 r. utworzyła rząd koalicyjny z innym postsolidarnościowym ugrupowaniem, jakim była - przekształcona z Unii Demokratycznej - Unia Wolności.

W 1997 r. uchwalona została nowa Konstytucja RP. Wyciągając wnioski z dotychczasowej historii transformacji ustrojowej, charakteryzującej się krótkotrwałością i zmiennością koalicyjnych rządów, wprowadzono do konstytucji konstruktywne votum nieufności dla rządu. Taka konstrukcja votum nieufności stanowiła istotny element wzmacniający rząd. Stąd też premier J. Buzek, stojący na czele rządu koalicyjnego AWS-UW, był pierwszym premierem pełniącym funkcje przez cały okres kadencji Sejmu. Sytuacja ta jednak nie zapewniła ani premierowi, ani formacji AWS zwycięstwa w kolejnych wyborach. Mogłoby się wydawać, że ustabilizowana AWS, jak i Unia Wolności pozostaną trwałymi elementami struktury politycznej. Tak się jednak nie stało. Utworzone w końcu kadencji J. Buzka ugrupowanie PiS przejęło część posłów AWS i w wyborach z 2001 r., zdobywając 9,6\% głosów, znalazło się w Sejmie. Z kolei Unia Wolności utraciła miejsce w Sejmie na rzecz nowo powstałego ugrupowania, jakim stała się Platforma Obywatelska, która przejęła część posłów UW.

Kształtowanie się sceny politycznej w okresie transformacji ustrojowej można zatem obserwować na dwóch poziomach, bardziej generalnym, dotyczącym systemu partyjnego oraz konkretnym, dotyczącym poszczególnych partii politycznych.

Nasuwa się niewątpliwie wniosek, ze scena partyjno-polityczna, głównie z uwagi na próg wyborczy, ewoluowała wyraźnie od sytuacji silnego rozdrobnienia partyjnego, powiązanego z niepewnością i kruchością rządów, do stabilnego systemu partyjnego, zapewniającego większościowe wsparcie parlamentarne rządowi, do czego także przyczyniła się instytucja konstruktywnego votum nieufności wobec premiera.

System ten jednak nie zapewniał trwałości poszczególnym partiom politycznym. Podczas całego okresu transformacji zaobserwować można pojawianie się i znikanie partii politycznych. Było to zrozumiałe w początkowym okresie, kie- 
dy pojawiały się drobne efemerydalne partie, jak - wspomniana już wcześniej - partia piwa czy podobne. Znikanie ze sceny politycznej dotyczyło jednak także i partii, które wydawało się, że są wyraźnie zakorzenione w systemie. Do nich zaliczyłabym niewątpliwie Unię Wolności czy AWS. Ich zniknięcie powodowane było jednak najczęściej wewnętrznymi tarciami w obrębie danej partii. Tak np. przegrana D. Tuska na szefa UW zdecydowała o dokonaniu rozłamu w Unii Wolności i stworzenia PO. Podobnie spory w koalicji AWS doprowadziły do utworzenia (z inicjatywy ówczesnego ministra sprawiedliwości) partii PiS, co w efekcie spowodowało zniknięcie ze sceny politycznej AWS.

Od 2005 r. można też było obserwować wyraźne przesuwanie się preferencji wyborczych w kierunku centrum z przechyłem na prawo. Jednakże reprezentacja lewicy zawsze w Sejmie się znajdowała, choć od 2005 r. nie była w stanie stworzyć koalicji rządowej. Sądzę też, że od 2005 r. dało o sobie znać dosyć wyraźnie zjawisko, które można nazwać personalizacją partii. Partie skupiały się wokół wyraźnych liderów, jakimi byli D. Tusk i J. Kaczyński. To oni wywierali istotny wpływ na funkcjonowanie i na spójność partii. Można to było w pełni zaobserwować po odejściu D. Tuska z funkcji lidera partyjnego. Silna partia zaczęła tracić na znaczeniu. Sam emblemat partii nie wystarczał. Utożsamiana była z liderem, którego zabrakło. Efekt personalizacji partii został natomiast mocno wykorzystany przez PiS.

W wyborach 2015 r., które odbyły się według zasad wprowadzonych przez Kodeks wyborczy z 5 stycznia 2011 r., PiS uzyskał zwycięstwo. Powstała zupełnie nowa sytuacja, mająca istotny wpływ na kształt sceny politycznej. Po raz pierwszy nie znalazło się w Sejmie żadne ugrupowanie lewicowe, co w dużej mierze było konsekwencją powielanego z początku transformacji zachowania się partii postsolidarnościowych, tj. pączkowania małych partii, które odbierały głosy zawartej koalicji i tym samym ani poszczególne partie, ani koalicja nie były w stanie przekroczyć progu wyborczego. Z tego też względu po raz pierwszy od 1989 r. zwycięski komitet wyborczy PiS zdobył większość sejmową umożliwiającą mu sformowanie samodzielnego rządu.

Czy zatem możemy mówić o ostatecznym ukształtowaniu się sceny politycznej w Polsce? Czy partie, które istnieją już 15 lat, a do takich należy zarówno PiS czy PO, i są nieprzerwanie w Sejmie, pozostaną na scenie politycznej? Jestem przekonana, że scena polityczna nie jest ostatecznie ukształtowana. Wręcz przeciwnie, system jest dynamiczny. Wyniki wyborów z 2015 r. pokazują to wyraźnie. W parlamencie znalazły się zupełnie nowe partie, jak Nowoczesna, zbliżona programowo do PO, której start w wyborach niewątpliwie osłabił PO, jak populistyczne, antysystemowe ugrupowanie Kukiz'15. Czy są to ugrupowania trwałe na scenie politycznej? Trudno przewidzieć. 
Doświadczenie okresu transformacji uczy, że znikały partie, które ulegały wewnętrznej erozji w sporze o władzę, a na ich miejsce powstawały nowe. Istotną rolę odgrywał także efekt wahadła, które w kolejnych wyborach może przesunąć się w kierunku lewicy. Trudno przewidzieć, jaka będzie ewolucja. Czy zmierzamy w kierunku systemu, w którym jedna partia będzie zdolna uzyskać kwalifikowaną większość głosów w parlamencie, czy też po okresie rządów jednej silnej partii, dysponującej bezwzględną większością nastąpi powrót do bardziej zróżnicowanego partyjnie parlamentu? Pozostawiam to pytanie otwarte. Ewolucja polskiego systemu partyjnego i w konsekwencji kształtu sceny politycznej jest, w moim przekonaniu, w dalszym ciągu nieprzewidywalna.

\section{BIBLIOGRAFIA:}

Gunther R., Ramon Montero J., Linz J. J. (eds.), Political Parties: Old Concepts and New Challenges, Oxford University Press 2002.

Kędzia Z., Hauser A., Analitical paper on the IPU survey concerning the impact of political party control over the exercise of the parliamentary mandate.

Lai B., Melkonian-Hoover R., Democratic Progress and Regress: the Effect of Parties on the Transitions of States to and Away from Democracy, Political Research Quarterly 2005 , vol. 58/4.

Skórzyński J., Obywatelski gabinet cieni, „Polityka” 4 listopada 2009. 